\title{
Neutralization of the Money Stock - Comment
}

\author{
by MICHAEL W. KERAN
}

\begin{abstract}
H ENERSHOTT raises some interesting issues with respect to my earlier critique of his neutralized money stock concept. Before considering the specific issues he raises, it would be useful to define certain relevant terms. This will allow us to more sharply focus the debate with respect to areas of agreement and disagreement.
\end{abstract}

\section{Terminology}

1) Federal Reserve Actions - A most comprehensive measure of Federal Reserve actions are changes in Federal Reserve holdings of government securities adjusted for changes in reserve requirements. Hendershott calls this $\left(P^{*}\right)$, and uses this as his measure of Federal Reserve policy actions. This measure simultaneously captures the two major policy instruments of the Federal Reserve: open market operations, and changes in reserve requirements. Other Federal Reserve policy instruments, such as the discount rate, are generally assumed either to move in line with $\left(P^{*}\right)$, or to be of lesser importance.

2) Defensive and Dynamic Operations - Federal Reserve actions ( $\left.P^{*}\right)$, as described in (1), can be divided into defensive operations and dynamic operations. Defensive operations are those Federal Reserve actions which are designed to prevent undesired changes in member bank reserves (or some other intermediate financial target) as a result of changes in factors not under the control of the Federal Reserve, such as offsetting gold flows or changes in Federal Reserve float. Dynamic operations are Federal Reserve actions designed to change the desired level of member bank reserves (or some other intermediate financial target) in response to changes in monetary policy. As dynamic operations represent the Federal Reserve economic policy actions, they are assumed to vary systematically over the business cycle.

3) Monetary Influence on the Economy-This should reflect the net impact of all monetary influences on the real sector of the economy, that is, employment, income, and prices. This influence may or may not be under the dominant control of the Federal Reserve, depending upon how the Federal Reserve has actually operated. The appropriate measure of this monetary influence depends upon the linkage between monetary variables and the rest of the economy. One's concept of these linkages depends upon one's assumptions about economic behavior. Keynesian income-expenditure theory has typically measured this influence by market interest rates, while the modern quantity theory has typically measured it by changes in the money stock.

Hendershott's concern is with the first point. He wishes to construct an unbiased measure of Federal Reserve policy actions. This is a useful exercise in its own right, but it cannot be considered as providing evidence or insight into point (3) listed above. The best measure of Federal Reserve policy actions is not necessarily the best measure of monetary influence on the economy. This second question requires a separate theoretical and empirical verification which is not attempted either by Hendershott or by me in this article. ${ }^{1}$

The author has considered the question of monetary influences on the economy in other articles. See Michael W. Keran, this Review, November 1969 and February 1970. 


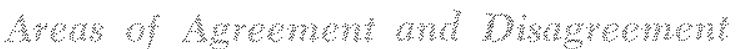

Hendershott points out that I am inconsistent in rejecting the neutralized money stock as a measure of monetary policy actions when I have presumably accepted the principle of neutralization with respect to government spending and tax receipts as a measure of fiscal policy actions. He then attempts to demonstrate that the error one makes in analyzing policy actions of the Federal Reserve without a neutralized money stock is of the same character as in analyzing policy actions of the Federal Government without "neutralized" receipts and expenditures.

I do accept the conceptual desirability of a neutralized money stock as an unbiased measure of Federal Reserve policy actions, with the previously mentioned caveat that this should not be considered as providing any information with respect to monetary influences on the economy. My disagreement with Hendershott is on the empirical relevance of his particular neutralization process.

I tried to make that point in my original article when I said, ". . . what if open market operations had not been conducted in a way to offset the infuence of borrowings and gold on the money stock? In that case Hendershott's neutralized money stock would have been a superior measure of Federal Reserve (policy) actions."'

My disagreement with Hendershott is with respect to the interpretation of Federal Reserve actions, $\left(\mathrm{P}^{*}\right)$. $I$ assert that this is a measure of both policy actions and non-policy actions related to offsetting non-controlled sources of member bank reserves. Stated in a somewhat different way, the Federal Reserve engages in both defensive operations and dyamic operations, and only the latter should be considered as policy actions. Hendershott, on the other hand, asserts that $\left(P^{*}\right)$ is an appropriate measure of "just" policy actions.

The issue which separates us is not theoretical bat empirical in nature. As such, it is subject to standard statistical tests. In the original article I presented such a statistical test. ${ }^{3}$ It indicated that a substantial share of the changes in $\mathrm{P}^{*}$ (I used the symbol $\mathrm{S}_{\mathrm{A}}$ ) could be explained by defensive operations designed to offset influences on member bank reserves from changes in non-controlled sources of reserves.

2Michael Keran, "Theply," this Review (August 1969), p. 17. 3 Ibid, p. 17.

Page 16
If the Federal Reserve had not acted in this sys. tematic way to offset non-controlled sources of reserves, then the question of whether the neutralized money stock was a superior measure of Federal Reserve policy actions would depend on how well Hendershott's explanation of public influences on these non-controlled sources of reserves stood up under critical analysis. Because Hendershott's results had not passed the first test, I did not examine his results in detail to see whether they had passed the second test.

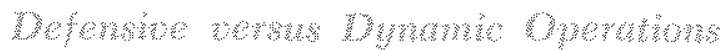

Hendershott argues that the public, through its influence on market interest rates, will influence certain sources of member bank reserves (specifically gold flows and member bank borrowing), and through this the observed money stock. When this public influence is estimated and removed, we have in the neutralized money stock an unbiased measure of Federal Reserve policy actions. My position is that whatever the cause of the gold flow or changes in member bank borrowing, the Federal Reserve has acted to systematically offset their infuence on member bank reserves through the standard and longstanding procedure of defensive operations. On the basis of empirically verifying the existence of defensive operations to offset the influences of gold and borrowings on member bank reserves, I asserted that the observed money stock is superior to the neutralized money stock as a measure of Federal Reserve policy actions.

Hendershott does not question the statistical results presented. On what basis then could he continue to press this position that $P^{*}$ measures Federal Reserve policy actions? $\mathrm{He}$ must assume that Federal Reserve defensive behavior is systematically different during periods when the Federal Reserve is following a tight money policy than during periods when it is following an easy money policy. That is, when the Federal Reserve wishes to follow an easy money policy it will not engage in net defensive operations which would tend to reduce total reserves of member banks. When the Federal Reserve is engaged in a tight money policy, it would not engage in net dem fensive operations which increase total reserves.

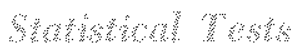

Only if Federal Reserve defensive operations are systematically different between periods of tight money and periods of easy money can Hendershott 
assert that all Federal Reserve actions ( $\mathrm{P}^{*}$ ) be evaluated in a uniform way rather than being divided into defensive and dynamic operations. Two tests of this possibility are made. The first is to compare Federal Reserve defensive operations during periods of tight money policy with defensive operations during periods of easy money policy. A "Chow" test will tell us whether the data for these subperiods were drawn from different behavior populations.

The second test focuses on gold flows and member bank borrowings from the Federal Reserve. Because these are the major factors causing the neutralized money stock to deviate from the actual money stock, it is desirable to see if the value of these defensive coefficients changes between periods of tight and easy money policy.

To make the tests in such a way as to provide the greatest chance to validate Hendershott's position, periods of tight money policy and easy money policy are constructed according to the breakdown given by Hendershott. ${ }^{4}$

\section{Tight Periods}

April 1955 - Nov. 1957

Aug. 1958 - March 1960

Jan. 1962 - Oct. 1962

\section{Easy Periods}

Aug. 1953 - April 1955

Nov. 1957 - Aug. 1958

March 1960 - Jan. 1962

Oct. 1962 - Dec. 1964
The results of the first test are presented in Table I. The dependent variable is Federal Reserve holdings of Government securities adjusted for a change in reserve requirements $\left(\Delta \mathrm{P}^{*}\right)$. The independent variables are all other factors which influence member bank reserves and are not directly controlled by the Federal Reserve. If the Federal Reserve engaged in defensive operations, the sign of the gold, float, and borrowing coefficients would be negative, and the sign of the currency coefficient would be positive. The sign of the "other" coefficient is indeterminant."

The first column shows the estimated coefficients for defensive operations in tight money periods, as designated by Hendershott, and the second column shows the estimated coefficients for his designated easy money periods. The Chow test, which is designed to test for a shift in the structure between these periods, was not significant at the 95 per cent level of confidence. There is no statistical evidence that the

EPatric Hendershott, "A Quality Theory of Money," Nebraska Journal of Economics and Business (Autumn 1969).

5This is becalse it is a combination of sources and uses of member bank reserves.

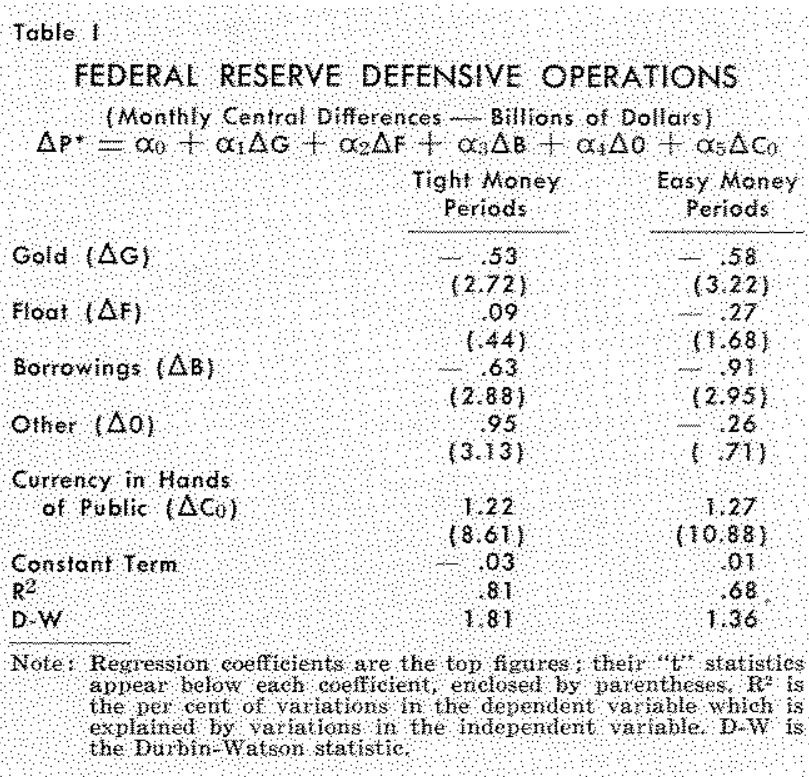

Federal Reserve conducted defensive operations differently during periods of easy money than during periods of tight money.

Even though there was no shift in the general structure of Federal Reserve behavior between subm periods of tight and easy money, it is possible that Federal Reserve actions with respect to particular variables could have changed between subperiods. Because gold and member bank borrowings were found by Hendershott to dominate the difference between the actual and the neutralized money stock, it is important to see whether there was a shift in the value of these coefficients between periods of tight and easy money. This is done in the second test, and the results are presented in Table II.

The second test estimates the value of coefficients for the same variables as in Table I for the entire period, and compares them to the coefficients for just the tight money periods. ${ }^{\top}$ If between periods of tight and easy money, the Federal Reserve had engaged in different defensive operations with respect to any

PPerfect defensive operations could have implied coeficients with absolute values close to 1.0 , in all cases the coefficients in Table I are significantly difierent from one (1) for both periods. Only defensive operations are accounted for in this regression. By introducing variables to account for dynanic operations, the estimations would have been more efficient. For an example of both defensive and dynamic operations as an explanation of $\Delta \mathrm{P}^{*}$, see Michael W. Keran and Christopher T. Babb, "An Explanation of Federal Reserve Actions (I933-68)", this Review (Euly 1969 ) pp. 7-20. In this later case, the values of the estimated defensive coefficients are not significantly different from one in absolute value.

"This approach uses multiplicative dummy variables which have the property of allowing for shifts in the slopes of the independent vartiables between the two periods. See Arthur S. Goldberger, Econometric Theory John Wiley and Sons, 1964), pp. 224-227. 


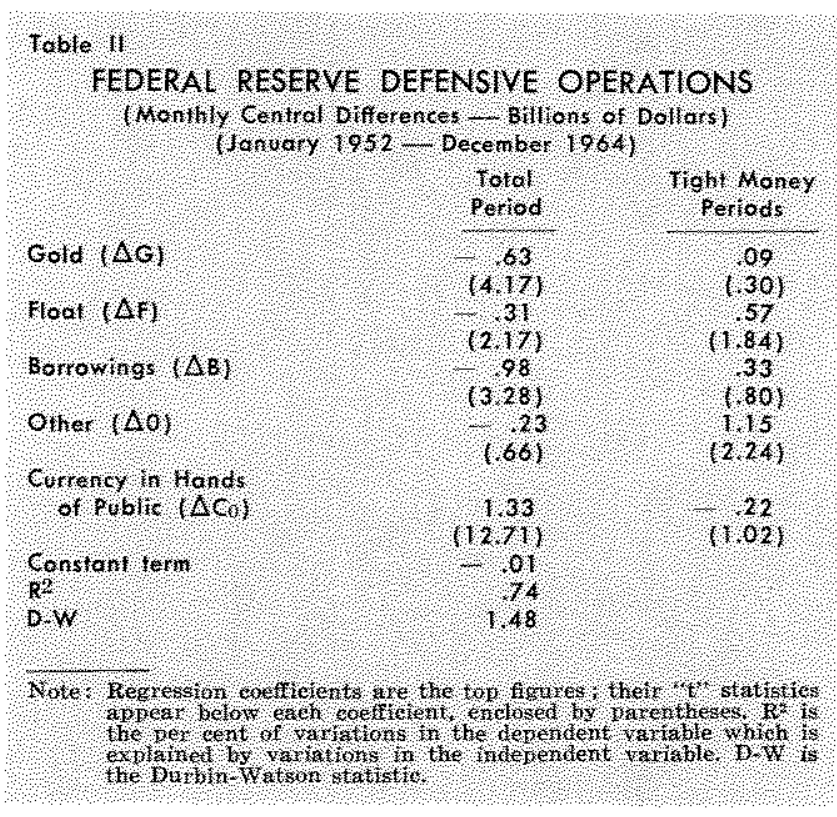

of the variables specified, the second series of estimated coefficients would be statistically significant. If the Federal Reserve had not responded in different ways between subperiods, then the second group of coefficients would not be statistically significant.

In Table II the $t$ statistics in the tight money period for gold and borrowings are statistically insignificant, which indicates that the Federal Reserve's response to these independent infuences on member bank reserves was not significantly different during periods of tight and easy money policy. There is no statistical evidence that the Federal Reserve had responded to changes in gold and borrowings differently during the subperiods.

The statistical tests represented in Table I and Table II are consistent with each other. The results in Table I show that total Federal Reserve defensive operations did not change between the two periods. Table II indicates that Federal Reserve behavior, with respect to gold and borrowings, did not change between subperiods. To state these results in statistical jargon, Hendershott's results have passed neither the $\mathrm{F}$ test (Table 1 ), nor the $\mathrm{t}$ test (Table II) of statistical significance. Therefore, it must be concluded that Federal Reserve defensive operations are not sensitive to changes in Federal Reserve policy, and that Hendershott is not justified in treating ( $P^{*}$ ) as responsive to "just" policy changes. Because the neutralized money stock does not consider the interaction between Federal Reserve holdings of Government securities $\left(\mathrm{P}^{*}\right)$ and other sources and uses of reserves, it is not an unbiased measure of Federal Reserve policy actions.

The above two articles are available as Reprint No. 56 . 